\title{
PERAN DAN TUGAS RECEPTIONIST PADA PT. SERIM INDONESIA
}

(Disadur dari Laporan Kerja Praktek mahasiswa dengan judul yang sama oleh Ayu Putri Utari, jurusan Sekretari D-3)

\section{Oleh: Ayu Putri Utari}

\author{
Disadur oleh: Dra. Nani Nuraini Sarah Msi
}

Nani20.sarah@gmail.com

\begin{abstract}
Reaching a Qualified Receptionist.

(This paper is excerpted from the final project report entitled 'The Role and Tasks of Receptionist in PT Serim Indonesia)

It is very usual if we walk-in an office, we are greeted by someone who is known as receptionist. A receptionist is an employee taking an office/administrative support position. The work is usually performed in a waiting area such as a lobby or front office desk of an organization or business. The title "receptionist" is attributed to the person who is employed by an organization to receive or greet any visitors, patients, or clients and answer telephone calls. Many small-to-large-sized business owners need receptionists for supporting their office activities.

The aim of this present paper is to explore the receptionists' jobs and the criteria to become qualified ones. As they are the front line that directly deal with customers, they must demonstrate their professionalism, such as courtesy, and making sure that customers are feeling welcome on their visiting experience.

Nowadays, even when the advancement of office automation has eliminated some receptionists' jobs. (e.g: a telephone call could be answered by an automated attendant). A receptionist who possesses strong office/technical skills and who is also adept in courtesy, tact and diplomacy is still considered an asset to a company's business image, and is still very much in demand in the business world.
\end{abstract}

Kata kunci: Receptionist, petugas kantor depan , staf administrasi.

\section{PENDAHULUAN}

\section{Latar Belakang}

Ketika kita memasuki sebuah kantor dan menjejakkan kaki kita pada sebuah kantor, umumnya kita disambut oleh seorang Satpam atau petugas yang akan mengarahkan kita menuju suatu ruang. Bisa saja kita disambut oleh seorang petugas yang pertama sekali menyambut tamu dan memberi salam kepada setiap tamu yang datang di dalam suatu ruangan. Ia lalu akan mendaftarkan tamu, menanyakan keperluan tamu, menghubungkan 
tamu dengan pimpinan/ karyawan/staff kantor yang dicarinya, atau sekedar memberikan informasi bagi tamu sehubungan dengan pelayanan/fasilitas yang tersedia di kantor serta informasi lainnya di luar perusahaan. Petugas ini dikenal dengan nama petugas kantor depan/Receptionist/Front Office Agent/ Front Desk Clerk

Setiap pimpinan perusahaan, baik perusahaan besar maupun perusahaan kecil memerlukan receptionist ataupun frontliner. Kehadiran receptionist pun sangat disarankan dalam suatu perusahaan untuk memberi informasi serta kesan kepada klien/tamu yang datang. Receptionist biasanya mempunyai area tersendiri, dalam ruang paling depan, terdepan dari kantor tersebut. Tidak banyak peralatan yang dimilikinya. Kadang hanya buku tamu saja, tetapi ada pula receptionist yang memiliki perangkat komputer, mesin fax, telepon dan intercom di mejanya. Namun ternyata ia menanggung tugas dan tanggungjawab yang besar karena akan memberi kesan pertama yang baik/buruk bagi perusahaan, arti kata lain adalah turut memberi citra positif. Para tamu yang bermaksud melakukan kerja sama dengan perusahaan menjadi lebih yakin untuk bekerjasama dengan perusahaan tersebut.

Sama halnya ketika kita memasuki sebuah rumah atau kantor, maka seringkali kita membuat penilaian atas rumah/kantor tersebut melalui pandangan pertama. Kesan terhadap rumah/kantor tempat kita datang biasanya mengiringi perasaan dan seringkali mempengaruhi penilaian rumah/personal kantor tersebut.

Receptionist biasa dikatakan sebagai tombak terdepan dari sebuah perusahaan atau pun hotel karena berhubungan langsung dengan tamu. Bersamaan dengan itu, receptionist ataupun frontliner di dalam sebuah perusahaan harus memberikan pelayanan prima. Yang dimaksud dengan Pelayanan prima adalah terjemahan dari "Excellent Service", yang berarti pelayanan terbaik. Beberapa pakar tentang Pelayanan Prima mengolah kata service menjadi lebih bermakna.

Mari kita lihat, harapan pelanggan terhadap pelayanan prima adalah:

1. Makin lama makin baik (better)

2. Makin lama makin cepat (faster)

3. Makin lama makin diperbaharui (newer)

4. Makin lama makin murah (cheaper)

5. Makin lama makin sederhana (more simple) 
Citra sebuah kantor dapat dilihat dari kinerja frontliner/receptionist. Menjadi seorang receptionist yang berkualitas tidak hanya berpenampilan baik dan berperilaku baik. Dia dituntut mampu berkomunikasi dengan tamu. Receptionist diharuskan menggunakan bahasa yang mudah dimengerti oleh tamu dengan tutur kata yang sopan dan halus sehingga tamu merasa nyaman dan dilayani dengan baik. Seorang receptionist juga harus menjadi orang yang cekatan, misalnya seorang receptionist akan selalu menyimpan nomor-nomor penting orang-orang di perusahaan, rekan kerja, atasan hingga klien. Ada saja saatnya seseorang membutuhkannya dan receptionist akan menjadi tempat bertanya mereka. Kadangkala seorang receptionist juga menyimpan berbagai dokumen penting yang mungkin dibutuhkan oleh atasan ataupun klien. Hal ini semata untuk membantu menghemat waktu saat mereka membutuhkan data-data tersebut.

Perusahaan merupakan Office Industry yang berarti Industri yang sangat mengutamakan hasil kerja, kenyamanan tamu dan keramahan staf kantornya. Citra dan kepuasan tamu menjadi sangat penting dalam industri perusahaan dan merupakan tolok ukur kenyamanan sebuah kantor.

Seorang mahasiswi saya terjun langsung menjadi seorang receptionist pada sebuah perusahaan di Cisauk, Tangerang; sehingga tulisan saya ini seputar bahasan mengenai peran dan tugas seorang receptionist pada PT Serim Indonesia, yaitu sebuah perusahaan yang bergerak dibidang pembuatan busa dan karet serta membuat bahan fungsional baru dengan unlimited karakteristik fungsional poliuretana busa fleksibel.

\section{Identifikasi Masalah}

Berdasarkan Latar Belakang di atas, maka dapat diidentifikasikan permasalahan sebagai berikut:

1. Peran receptionist perusahaan

2. Tugas dan tanggungjawab receptionist perusahaan

3. Kemampuan komunikasi receptionist

4. Hubungan receptionist dengan citra perusahaan

5. Hambatan dan kendala seorang receptionist

\section{Pembatasan Masalah}

Mengingat luasnya cakupan masalah, maka penulis membatasi permasalahan hanya pada Peran dan Tugas Receptionist pada PT. Serim Indonesia. 


\section{Perumusan Masalah}

Dari permasalahan yang telah penulis kemukakan, maka penulis merumuskan beberapa permasalahan, yaitu:

1. Tugas dan peran receptionist di PT. Serim Indonesia

2. Seberapa jauh receptionist di PT. Serim Indonesia melaksanakan tugasnya.

\section{Tujuan Penelitian}

Tujuan dan manfaat yang hendak dicapai dari penulisan ini adalah:

1. Untuk mengetahui dan memahami peran dan tugas receptionist pada sebuah perusahaan.

2. Sejauh mana receptionist PT Serim Indonesia melaksanakan tugas-tugasnya.

\section{DESKRIPSI TEORITIK}

\section{Definisi Receptionist}

Receptionist atau penerima tamu di bagian kantor terdepan memiliki banyak istilah atau sebutan. Ada yang menyebutkannya dengan istilah Front Desk Agent, Front Desk Clerk, Guest Service Agent dan Guest Room Service. Semua istilah yang disebut di atas sama artinya, hanya saja cara penyebutannya berbeda, sebagaimana dijelaskan oleh J.Martin(1991:45) dalam bukunya Human Relation for the Hospitality Industry

\section{Peranan Receptionist atau Kantor Depan}

Receptionist memiliki peranan penting bagi perusahaan terutama dari segi citra dan pelayanan perusahaan terhadap konsumen, perusahaan rekanan maupun tamu perusahaan.Receptionist diwajibkan memiliki keramahan dalam pelayanan kepada pihak luar perusahaan.Selain itu receptionist juga harus memiliki etika yang baik dan komunikasi yang baik dalam menjalankan tugas- tugasnya. Biasanya training akan membantu para recepsionist untuk menjadi recepsionist yang handal sehingga dapat memberikan citra postitif pada perusahaan.

\section{Tugas dan Tanggung Jawab Receptionist.}

Didalam suatu perusahaan maupun hotel ada beberapa Tugas dan Tanggung Jawab Receptionist, yaitu: 
a. Tidak membuat tamu menunggu terlalu lama.

b. Memberi salam dan menegur tamu dengan ramah, sopan dan menanyakan keperluan tamu serta mempersilahkan tamu mengisi kartu atau buku tamu.

c. Perhatikan kepentingan-kepentingan tamu perusahaan. Jika orang yang hendak ditemui tidak ada atau sedang pergi, tanyakan apakah dia bersedia menunggu (membuat tamu merasa senang apabila terpaksa harus menunggu)

d. Apabila pimpinan tidak dapat menerima tamu, berikan penjelasan dengan baik dan jangan sampai menyinggung tamu.

e. Memberikan perhatian kepada setiap tamu dan segera mengambil keputusan apabila tamu disalurkan ke bagian lain.

f. Dapat mengarahkan tamu, memberi informasi yang dibutuhkan dan membantu pimpinan dalam melayani serta membuat perjanjian dengan tamu.

g. Sebagai penerima tamu harus dapat menjaga pembicaraan dan mengerti tentang apa yang boleh dan tidak boleh untuk dibicarakan dengan tamu.

h. Hindari mengunyah permen karet atau makanan kecil saat menghadapi tamu atau saat menerima telepon.

i. Hindari bergerombol dengan teman kerja anda di meja receptionist, apabila untuk keperluan yang tidak ada hubungannya dengan pekerjaan.

j. Menyingkirkan barang-barang yang tidak berhubungan dengan pekerjaan di meja kerja.

k. Hindari mondar-mandir di ruang tamu dengan sandal atau penampilan yang tidak rapi.

1. Hindari mengobrol atau bergosip dengan teman kerja anda.

\section{Syarat Menjadi Receptionist Perusahaan dan Hotel}

Receptionist adalah seorang petugas di perusahaan/hotel yang bertanggung jawab untuk menerima tamu. Oleh karena itu kehadiran receptionist juga dapat memberi impressi/gambaran (citra) suatu kantor.

Oleh karena itu, receptionist perusahaan maupun hotel wajib memiliki kemampuan sebagai berikut: 
a. Berkepribadian yang baik.

Seorang receptionist harus memiliki kepribadian yang baik dan menyenangkan, yang senantiasa selalu siap membantu tamu bila diperlukan, senang berhubungan dengan tamu dan orang lain serta dapat menjadi pendengar yang baik.

b. Rasa Tanggap

Dalam hal ini receptionist dituntut untuk dapat mengambil keputusan dengan cepat dan tepat dalam menghadapi situasi di kantor depan.

c. Diplomatis

Kerjasama yang harmonis baik dengan atasan, sesama rekan kerja, bawahan maupun dengan departemen lainnya sangat diperlukan demi kelancaran pekerjaan.Untuk itu, receptionist harus memiliki keinginan untuk saling membantu dan menghormati.Tidak hanya pada saat bekerja tetapi juga di luar pekerjaan.

d. Kerjasama yang harmonis baik dengan atasan, sesama rekan kerja, bawahan maupun dengan departemen lainnya sangat diperlukan demi kelancaran pekerjaan.Untuk itu, receptionist harus memiliki keinginan untuk saling membantu dan menghormati.Tidak hanya pada saat bekerja tetapi juga di luar pekerjaan.

e. Penampilan yang baik, rapi dan bersih

Hal ini tidak saja berhubungan dengan kepribadian receptionist yang bersih dan rapi, tetapi juga mencakup hal-hal yang ada disekitarnya, misalnya peralatan kerja seperti alat-alat tulis harus tersusun rapi diatur pada tempatnya. Tamu akan merasa terkesan dan merasa puas dengan pelayanan yang diberikan oleh receptionist yang baik, rapi dan bersih.

\section{Karakteristik receptionist yang ideal}

\section{Ditinjau dari aspek kepribadiannya}

Menurut Ny.Yoesoef Noesyiwan, ada 4 (empat) aspek kepribadiaan seseorang bila menjadi receptionist, yaitu :

a. Vitalis adalah semangat pribadi seseorang, pusat tenaga yang relative konstan atau menetap. Vitalitas merupakan dasar kepribadian yang menentukan kemampuan berprestasi, sikap hidup dan sikapnya terhadap sesama manusia.

b. Temperamen adalah warna-warna emosi penghayatan dan pengalaman,berupa cara seseorang bereaksi terhadap suasana jiwanya. 
Seseorang yang mempunyai warna penghayatan gembira tidak akan mudah ditimpa kemalangan. Sebaiknya seseorang dengan penghayatan sedih akan berada dalam kesedihan secara berkepanjangan dan akan menutup diri dari lingkungannya.

c. Watak adalah inti atau hakikat kepribadian atu hasrat, perasaan, dan kehendak merupakan kelanjutan dari hasrat.

d. Bakat adalah sebuah kemampuan diri seseorang timbul karena bakat dan kemampuan. Dengan perkataan lain, walaupun seseorang berbakat tetapi kemampuannya kurang tentu .

\section{Ditinjau dari sifatnya}

Sifat-sifat positif sebaiknya dimiliki pula oleh seorang receptionist, seperti:

a. Gigih

Seorang receptionist selalu mengerjakan pekerjaan yang sama dari pagi hingga sore. Kebosanan adalah kata pertama yang harus dihadapi.Karena kebosanan bisa mengarahkan receptionist pada keteledoran dalam pekerjaannya.Misalnya, menghadapi tamu perusahaan dengan wajah yang tidak ramah \& senyum yang tidak tersungging di bibir.Atau juga, lupa menukarkan KTP tamu dengan ID card "tamu"/"pengunjung" pada tiap tamu perusahaan yang datang.Oleh karena itu, receptionist harus mampu membawa dirinya untuk selalu tampil prima dan fresh.

b. Baik dan ramah

Baik karena selalu memberikan layanan terbaik kepada antar bagian dalam perusahaan dan kepada perusahaan lain. Receptionist di perusahaan tertentu, ada kalanya ditugaskan untuk menyambungkan antar bagian dalam perusahaan melalui telepon intra-perusahaan. Receptionist juga harus ramah kepada perusahaan lain, karena ini adalah salah satu cara untuk menampilkan citra baik perusahaan.

c. Kenal dengan banyak orang dan tahu posisi mereka di perusahaan. Receptionist harus ramah kepada karyawan dalam perusahaan, receptionist harus mengenali berbagai nama dan posisi yang jumlahnya sangat banyak itu. Maka dari itu, beberapa karakter seringkali menjadi kriteria untuk menjadi seorang receptionist.Misalnya, supel. Supel berarti pandai bergaul. Biasanya mereka yang berkarakter supel, mudah untuk mengingat wajah, nama dan 
"siapa" orang lain itu. Terkadang, mereka adalah pribadi yang SKSD "sok kenal sok dekat”. Karakter seperti inilah yang akan sangat menunjang karir seorang receptionist yang handal.

d. Bahasa Inggris

Sebagai bahasa internasional harus juga dikuasai oleh receptionist. Hal ini dikarenakan, bahasa inggris merupakan bahasa pergaulan yang dipakai secara internasional. Bertemu dengan tamu dari negara lain, ekspatriat dari eropa atau amerika, misalnya. Bahkan, kadang-kala eksekutif perusahaan harus diajak berkomunikasi dalam bahasa Inggris.

\section{Ditinjau dari penampilan dirinya (grooming)}

Karena receptionist juga bersinggungan langsung dengan tamu, maka tampilan fisiknya harus mendapat perhatian khusus sebagai berikut:

a. Kebersihan diri

1) Menggunakan parfum secukupnya, dengan aroma yang lembut dan tidak menyengat.

2) Menjaga kebersihan rambut dan menyisir hingga rapi.

3) Menjaga kebersihan jari tangan dengan memotong kuku.

b. Ketentuan tentang seragam

1) Menggunakan seragam yang telah disediakan oleh Perusahaan serta menyesuaikan dengan ketentuan yang berlaku.

2) Menggunakan sepatu yang sopan.

Sedangkan grooming secara psikis, menyangkut beberapa hal sebagai berikut:

a. Pada saat bekerja wajah selalu dalam keadaan fresh dengan ekspresi muka yang menyenangkan.

b. Menunjukkan sikap positif terhadap perusahaan dan pekerjaan.

c. Selalu bersikap diplomatis dalam menghadapi masalah serta menghindari emosi yang berlebih.

1) Tidak mengutamakan urusan pribadi dalam pekerjaan.

2) Berbicara dan menanggapi pembicaraan secara intelek.

3) Dapat mengerti gagasan orang lain dan dapat bekerja dalam tim.

\section{Ditinjau dari kemampuan Receptionist berkomunikasi}


Menurut Prof Widjaja, seorang receptionist dapat mengembangkan kemampuan berkomunikasinya dengan melakukan hal-hal sebagai berikut:
a. Berpandangan positif
b. Tanggap terhadap keinginan pihak lain
c. Kembangkan kemampuan menyimak
d. Terbuka
e. Selaras dan spesifik
f. Tentukan mana yang penting dijalankan dan diabaikan
g. Sediakan waktu untuk pembicaraan intim
h. Tetaplah optimis secara realistic
i. Beda pendapat, hindarkan debat
j. Terbuka pada pendapat lain
k. Utamakan tindakan, jangan sekedar kata-kata.
1. Menerima dan mengerti perasaan
m. Bertanya tapi, tidak mengumpat dibelakang
n. Penuh pertimbangan sebelum melakukan
o. Sopan dan punya rasa hormat kepada orang lain

Dalam mengembangkan kemampuan berkomunikasi, komunikator tidak ragu-ragu dan memiliki sikap yang mantap. Disamping ke lima belas butir tersebut, syarat-syarat yang harus diperhatikan antara lain: Memiliki kredibilitas yang tinggi, memiliki ketrampilan berkomunikasi, memiliki pengetahuan yang luas, memiliki sikap yang baik terhadap komunikan, dan memiliki daya tarik. (Komunikator adalah orang yang menyampaikan pesan, dan komunikan adalah orang yang menerima pesan)

\section{Kunci dalam Berkomunikasi}

\section{a. Mendengar dan Mendengarkan}

Pada bagian ini disampaikan tentang cara untuk meningkatkan kualitas hubungan antar manusia, salah satu diantaranya adalah dengan cara "mendengar", yang merupakan sebuah proses yang mana dapat memberikan informasi.

Mendengarkan (listening) adalah suatu proses yang rumit, yang kita gunakan untuk membuat rasa akan apa yang kita dengar. Pendengaran adalah (hearing) 
proses psikologis dari menerima (decoding) suara. Menurut Beebe, Beebe, dan Redmond (1996:99), tanpa kita sadari, kita menghabiskan banyak waktu untuk mendengarkan orang lain dari pada hal lainnya yang kita lakukan, seperti terlihat dalam gambar lempengan berikut ini :

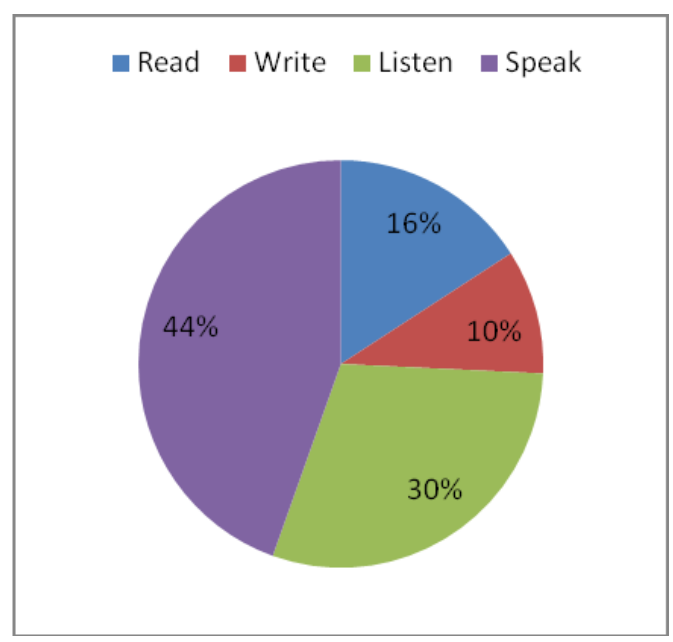

Gambar 4.1 Perbandingan membaca, menulis, mendengar dan berbicara

Sumber : Beebe, Beebe, dan Redmond (1996:99)

Jika mengutip jawaban Sir Edmund Hillary tentang mengapa mendaki gunung Mount Everest adalah karena gunung itu ada, maka mendengar juga karena ada kata-kata di sini. Tetapi kita juga mendengar karena kita butuh untuk berhubungan dengan manusia lain. Hal ini menjelaskan bahwa upaya mendengar kan harus disiapkan sebagai upaya untuk membangun dan meningkatkan hubungan. Ada beberapa alasan mengapa kita mau mendengar, antara lain untuk hal-hal sebagai berikut:

1) Mendengar untuk kenikmatan/kesenangan

2) Mendengar untuk belajar

3) Mendengar untuk mengevaluasi

4) Mendengar untuk ber-empati dengan pihak lain

\section{b. Keterampilan Mendengarkan}

Ada banyak masalah seputar perihal mendengar.Kita dapat mengidentifikasinya dari fokus pada diri kita sendiri pada pengirim pesan lainnya.Kita dapat mulai meningkatkan keterampilan mendengar kita dengan mengikuti 3 (tiga) langkah berikut :

1). Stop 
Berikut sebuah model akan bagaimana kita belajar berbagai keterampilan, menurut Abraham Maslow, menyarankan bahwa kita menjalankan satu dari empat tingkatan keterampilan sebagai berikut :

a) Unconcious incompetence (Tidak sadar ketidakmampuan)

b) Kita tidak tahu apa yang kita tidak tahu

c) Conscious incompetence (sadar ketidakmampuan)

d) Kita tahu apa yang kita tidak tahu

e) Conscious competence ( Sadar kemampuan)

f) Kita tahu apa yang kita tahu

g) Unconcious competence (Tidak sadar kemampuan)

h) Kita tidak tahu apa yang kita tahu

2. Lihat (Look)

Adalah menjadi sadar akan isyarat nonverbal pembicara, amati isyarat nonverbal kamu sendiri untuk mengkomunikasikan kepedulianmu pada pembicara.

3. Dengar (Listen)

Membandingkan makna/maksud dari fakta dan detail dari pesan temanmu

\section{Hambatan - Hambatan Komunikasi}

Menurut Effendy (1993:50-51), hambatan komunikasi pada umumnya mempunyai dua sifat, yaitu sebagai berikut :

a. Hambatan yang bersifat objektif, yaitu gangguan dan halangan terhadap jalannya komunikasi yang tidak disengaja dibuat oleh pihak lain, tapi mungkin disebabkan oleh keadaan yang tidak menguntungkan, misalnya gangguan cuaca. Namun, rintangan atau hambatan objektif ini juga dapat dikarenakan kurangnya kemampuan berkomunikasi (field of experience) yang tidak " in tune" antara komunikator dengan komunikan, pendekatan yang kurang baik, waktu yang kurang tepat, penggunaan media yang keliru, dan sebagainya.

b. Hambatan yang bersifat subjektif, ialah gangguan yang sengaja dibuat oleh orang lain, sehingga merupakan gangguan, penentangan terhadap suatu usaha komunikasi dan dasar gangguan ini biasanya bersifat tamak, iri hati, pertentangan kepentingan dan sebagainya. 
Mengutip pendapat tentang dua jenis gangguan terhadap jalannya komunikasi, menurut sifatnya dapat diklasifikasikan sebagai gangguan mekanik dan gangguan semantic.

a. Gangguan Mekanik ( mechanical, channel noise)

Adalah gangguan yang disebabkan saluran komunikasi atau kegaduanyang bersifat fisik.

b. Gangguan Sematic (sematic noise)

Gangguan jenis ini bersangkutan dengan pesan komunikasi yang pengertiannya menjadi rusak.Gangguan sematic tersaring ke dalam pesan melalui penggunaan bahasa. Lebih baik kekacuan mengenai pengertian suatu istilah atau konsep yang terdapat pada komunikator, akan lebih banyak gangguan semantic dalam pesannya. Gangguan semantic terjadi dalam salah pengertian, baik pengertian denotative (denotative meaning) maupun pengertian konotatif (connotative meaning).

\section{Definisi Citra Perusahaan}

Citra perusahaan adalah kesan, perasaan, dan gambaran, seseorang terhadap suatu perusahaan, kesan yang sengaja diciptakan dari suatu obyek, orang, atau organisasi.

a. Menurut Kotler dan Amstrong (2006:299) dalam Perdananingtyas (2013), Citra perusahaan adalah seperangkat keyakinan, ide dan kesan yang dimiliki oleh seseorang terhadap suatu perusahaan.

b. Menurut Bill Canton dalam Soleh dan Elvinaro (2005:111) dalam Perdananingtyas (2013), Citra perusahaan adalah kesan, perasaan, gambaran diri publik terhadap suatu perusahaan, kesan yang dengan sengaja diciptakan dari suatu obyek, orang atau organisasi.

c. MenurutKatz dalam Soleh dan Elvinaro (2005:111) dalam Perdananingtyas (2013), Citra perusahaan adalah cara bagaimana pihak lain memandang sebuah perusahaan, seseorang, suatu komite atau suatu aktivitas.

\section{Manfaat Citra Perusahaan}

Menurut Siswanto Sutojo (2004:3) mengemukakan bahwa manfaat citra perusahaan yang baik dan kuat ialah untuk:
a. Memberi daya saing menengah dan panjang yang mantap
b. Menjadi perisai selama krisis
c. eksekutif handal
d. Meningkatkan efektivitas strategi pemasaran 
e. Penghematan biaya operasional

\section{Komponen Citra Perusahaan}

Konsumen menilai citra perusahaan tidak hanya berdasarkan kualitas fungsional saja, tetapi juga didasarkan pada atribut psikologis yang dicerminkan oleh perusahaan tersebut.

Menurut Nguyen dan Leblanc (2002:58) dalam Susilawati (2014):

menjelaskan bahwa terdapat dua komponen dasar citra perusahaan, yaitu sebagai berikut:

a. Komponen fungsional, dimana komponen fungsional berkaitan dengan atribut yang dapat diukur dengan mudah.

b. Komponen emosional berkaitan dengan dimensi psikological, yaitu perasaan dan sikap konsumen terhadap perusahaan, yang didasarkan pada pengalaman konsumen saat berinteraksi dengan perusahaan dan atribut informasi yang menggambarkan citra perusahaan tersebut.

\section{Dimensi Citra Perusahaan}

Setiap perusahaan pasti mempunyai citra dimata publiknya, citra tersebut dapat dipersepsikan berbeda oleh setiap orang tergantung pada persepsi yang dilihat mereka mengenai apa yang mereka rasakan terhadap citra perusahaan tersebut. Citra itu dapat berdampak positif atau negatif.

Menurut Shirley Harrison (2007:71) dalam Susilawati (2014), dimensi citra perusahaan ada empat, antara lain :

a. Personality (Kepribadian), yakni keseluruhan karakteristik perusahaan yang dipahami oleh lingkungan di luar perusahaan, misalnya keyakinan pada perusahaan, dan tingkat tanggungjawab sosial.

b. Reputation (Reputasi), yakni keyakinan seseorang terhadap perusahaan berdasarkan pengalaman pribadi atau orang lain atas jasa atau produk perusahaan, kenyamanan ketika menggunakan pelayanan pada jasa perusahaan tersebut.

c. Values/Ethics (Nilai/Etika), yakni nilai-nilai dan filosofi yang dianut perusahaan, misalnya keramahan pelayanan, gaya kerja, dan komunikasi baik internal perusahaan maupun interaksi dengan pihak luar.

d. Corporate identity (Identitas Korporat), yakni identitas dalam nama, simbol, logo, warna dan ritual untuk memunculkan perusahaan, merek dan kepentingan perusahaan 


\section{HASIL PENELITIAN DAN PEMBAHASAN}

Dari pengamatan lapangan, didapat hal-hal berikut:

\section{Penempatan Receptionist PT. Serim Indonesia}

Receptionist PT. Serim Indonesia ditempatkan di bagian depan kantor, duduk di lobby dengan meja kayu yang berdesign huruf L. Peralatan yang ada pada meja receptionist adalah sebuah mesin PABX disebut Private Automatic Branch Exchange, atau Alat Penyambung (Switch) yang fungsinya adalah untuk mengatur sambungan telepon masuk dan telpon keluar secara efisien dan efektif. Alat ini biasa digunakan di kantor, ruko, rumah besar/bertingkat, asrama, kost, dan bangunan besar lainnya. Fungsi dari mesin PABX ini sebagai sistem penyambungan telepon untuk mengatur proses penyambungan komunikasi telepon diperusahaan.

Peralatan tulis menulis yang dimiliki receptionist adalah bolpoin dan kertas dan fungsinya untuk mencatat pesan yang masuk dan disampaikan kepada orang yang bersangkutan. Terdapat juga sebuah daftar yang berisi nomer telepon atasan serta nomer extention dari divisi yang ada dikantor dan staff kantor lain, serta beberapa nomer customer yang biasa dihubungi.

Fungsinya agar jika ada hal yang penting bisa langsung menghubungi orang yang dituju.

\section{Tugas yang dilakukan receptionist PT. Serim Indonesia}

\section{a. Menerima Tamu yang Datang}

Tugas receptionist pada PT. Serim Indonesia adalah menerima tamu yang datang, dan receptionist tersebut menangani tamu itu dengan sopan dan ramah. Receptionist menanyakan maksud dan tujuan tamu tersebut datang dan apabila atasan/ staff yang dituju berada di tempat maka tamu tersebut diminta untuk menunggu di guest room,sementara receptionist memberitahukan bahwa ada customer yang ingin bertemu. Keperluan tamu tersebut bermacam-macam, seperti membicarakan kerjasama, ada pula juga yang menawarkan untuk mempromosikan produk-produk PT. Serim Indonesia.Apabila atasan/staff yang dituju tidak berada ditempat, maka receptionist menawarkan staff lainnya yang mungkin dapat menangani maksud dan tujuan tamu tersebut. Apabila 
tamu tersebut ingin tetap berbicara/bertemu dengan staff tertentu itu saja, maka receptionist menawarkan tamu tersebut untuk meninggalkan pesan.

\section{b. Menerima Telepon Masuk dan Keluar}

Tugas receptionist di PT Serim Indonesia yaitu menerima telepon masuk, misalnya dari customer dan supplier yang ingin berbicara dengan divisi lain. Lalu receptionist segera menyambungan telepon tersebut kebagian yang bersangkutan misalnya kepada marketing di PT Serim Indonesia dengan carareceptionist menanyakan dari mana telepon tersebut berasal, yaitu dari PT Nikomas Adidas.

Apabila direktur/staff yang dicari tidak ada ditempat, maka receptionist meminta penelpon untuk meninggalkan pesan. Yang dicatat receptionist dalam buku catatannya adalah:

1) nama penelpon

2) nama perusahaannya

3) nomer teleponnya

4) isi pesannya

Apabila direktur/staff yang dicari berada ditempat, maka receptionist menanyakan maksud dan tujuan si penelpon. Sebelum di sambungkan ke direktur/staff.

Apabila receptionist harus melakukan panggilan telepon keluar, maka receptonist akan memutarkan nomer telepon yang diminta dan setelah tersambung, maka sambungan akan diberikan kepada atasan/staff yang meminta.

Apabila receptonist harus melakukan panggilan telepon keluar dan tidak berhasil maka receptionist akan menunggu beberapa saat untuk melakukan panggilan ulang. Apabila telah beberapa kali dan tetap tidak berhasil, maka receptionist melapor kepada atasan/staff yang meminta dan bertanya apakah dapat ditelpon kembali setelah waktu makan siang, atau sore hari, misalnya. Pada keadaan tertentu adakalanya receptionist diminta atasan/staff untuk menyampaikan pesan saja kepada nomer telepon yang dituju. Misalnya ada Telepon dari Luar, receptionist hanya menerima telepon tersebut saja. Selanjutnya receptionist langsung menyambungankan telepon tersebut kepada atasannya.Dan Receptionisthanya memakai bahasa indonesia ketika menerima telepon dari luar negeri. 
Media komunikasi yang digunakan adalah pesawat telepon PABX dan sarana komunikasi yang dipakai adalah dengan menggunakan bahasa Indonesia yang baik dan benar. Receptionist menggunakan bahasa yang sopan serta mengeluarkan nada lembut dan ramah.

\section{c. Tugas Tambahan}

Selain melakukan tugas-tugasnya diatas tadi, receptionist PT Serim Indonesia juga mempunyai tugas membuat tanda terima yang nantinya akan digunakan oleh supplier untuk mengambil giro atau pembayaran. Receptionist diberi wewenang untuk menandatangani tanda terima ini. Yang memberikan tugas ini adalah marketing manager.

\section{Cara Receptionist Berkomunikasi}

Kemampuan receptionist dalam berkomunikasi dilihat dari hasil pengamatan penulis, bahwa receptionist PT. Serim Indonesia telah menggunakan bahasa yang mudah dimengerti oleh tamu dan dengan tutur kata yang sopan, halus sehingga tamu tersebut merasa nyaman dan dilayani dengan baik.

\section{Peran Receptionist dalam pencitraan}

Di dalam sebuah perusahaan citra kantor diberikan oleh seluruh staf dan karyawan, termasuk oleh receptionist. Sehingga penampilan receptionist sangat penting. Tolak ukur kenyamanan didalam sebuah kantor dapat diberikan oleh seorang receptionist ketika menyambut tamunya. Hal ini telah diberikan dengan baik oleh receptionist PT. Serim Indonesia

Pencitraan sebuah perusahaan juga dapat dilihat dari pakaian sergam yang dikenakan staf dan karyawannya. Citra yang diberikan receptionist di PT Serim Indonesia dapat dilihat dari baju yang dikenakan oleh receptionist. Ia mengenakan seragam yang telah disediakan dari perusahaan, recepsionist ini memakai sepatu berwarna hitam yang sopan sehingga ia terlihat berpenampilan menarik.

\section{Kendala dalam Pekerjaan}

\section{a. Pesawat PABX tidak berfungsi}

Kendala yang dihadapi receptionist di PT SERIM INDONESIA adalah apabila pesawat PABX tidak berfungsi. Receptionist selalu memeriksa sambungan telepon mesin PABX setiap pagi. Bila ada kerusakan atau gangguan yang terjadi 
maka sambungan komunikasi telepon antar customer dan staff terganggu. Bila saluran telepon mengalami gangguan, maka receptionist langsung menghubungi bagian teknisi agar di perbaiki. Apabila sambungan listrik mengalami gangguan PLN, maka mesin PABX tidak berfungsi sama sekali, karena mesin PABX menggunakan saluran listrik.

\section{b. Receptionist tidak masuk}

Karena receptionist di PT. Serim Indonesia hanya seorang diri, maka ketika receptionist ini berhalangan hadir/sakit, maka tidak ada receptionist pengganti. Namun pimpinan biasanya menunjuk seorang staff untuk menggantikan tugas beliau.

\section{KESIMPULAN DAN SARAN}

\section{Kesimpulan}

Berdasarkan hasil penelitian dan pembahasan yang telah diuraikan penulis, maka diambil kesimpulan sebagai berikut :

1. Receptionist di PT. Serim Indoneia selalu datang tepat waktu .

2. Receptionist menempati ruang tersendiri dibagian depan kantor dengan peralatan tulis menulisnya yang digunakan untuk mencatat apa-apa yang perlu dicatat, termasuk pesanpesan telepon yang masuk.

3. Tugas seorang receptionist pada PT. Serim Indonesia adalah menerima tamu, menerima telepon masuk dan telepon keluar, menerima dan menyampaikan pesan telepon telah dilaksanakan dengan baik. Receptionist telah melakukan tugas dan pekerjaannya dengan baik dan benar.

4. Receptionist di PT Serim Indonesia juga diberi tugas tambahan, yaitu membuat tanda terima yang akan diberikan kepada supplier dan customer yang memesan busa. Tugas ini diluar tugas dan tanggung-jawab seorang receptionist. Namun receptionist PT. Serim Indonesia menjalankan tugas yang diberikan kepadanya ini dengan baik.

5. Dari hasil pengamatan penulis, Receptionist di PT. Serim Indonesia telah melakukan komunikasi dengan baik. Ia menggunakan bahasa yang dimengerti oleh tamu yang datang, dan menggunakan bahasa Indonesia yang baik dan benar serta suara yang merdu baik kepada tamu yang datang, maupun ketika berbicara di telepon. 
6. Peran receptionist dalam membawakan citra perusahaan dapat dilihat dari cara ia mengenakan seragam yang telah disediakan oleh PT. Serim Indonesia. Perilaku receptionist yang sopan juga menambah citra positif bagi perusahaan. Hal ini dan dapat dilihat dari cara ia menyapa tamu dengan baik dan ramah.

\section{Masukan dan Saran}

Dari uraian kesimpulan diatas, penulis melihat upaya receptionist dalam bekerja telah maksimal dan diharapkan agar tetap dipertahankan dikemudian hari. Namun demikian ada sedikit saran yang ingin penulis sampaikan disini, sebagai berikut:

Peralatan tulis menulis:

Sebaiknya receptionist mencatat pesan telepon yang masuk di dalam sebuah buku yang dibuat dengan kolom-kolom sebagai berikut:

\begin{tabular}{|l|l|l|l|}
\hline $\begin{array}{l}\text { Hari / } \\
\text { Tanggal }\end{array}$ & $\begin{array}{l}\text { Nama dan } \\
\text { No. Penelpon }\end{array}$ & $\begin{array}{l}\text { Staff yang } \\
\text { dituju }\end{array}$ & Isi Pesan \\
\hline $\begin{array}{c}\text { Selasa/ } \\
17 \text { okt. }\end{array}$ & Pak Andi 0821667490 & Pak & $\begin{array}{l}\text { Menanyakan } \\
\text { kontrak } \\
\text { kerja }\end{array}$ \\
\hline 015 & & & \\
\hline
\end{tabular}

Maksud Tujuan dari pembuatan gambar diatas adalah agar receptionist tidak membuat kesalahan dalam menyampaikan isi pesan. Dengan adanya catatan diatas diharapkan tidak ada satupun pesan-pesan yang terlewatkan atau terlupakan. Selain itu pekerjaan receptionist dapat diperiksa/diawasi oleh atasan/ staff lain.

Menurut hemat penulis receptionist harus membuat buku catatan seperti diatas mengingat banyaknya atasan/divisi yang memberi tugas.

\section{Tugas tambahan:}

Sebaiknya receptionist tidak melakukan pembuatan Tanda Terima (tugas tambahan yang diberikan marketing manager), namun sekiranya ia harus melakukan tugas tersebut, maka penulis menyarankan agar semua Tanda Terima yang dibuat dan ditandatanganinya dicatat dalam sebuah buku catatan tersendiri. Seperti contoh dibawah ini. Hal ini untuk menghindari hal-hal yang tidak diinginkan dikemudian hari. 


\begin{tabular}{|l|l|l|l|l|}
\hline $\begin{array}{l}\text { Hari / } \\
\text { Tanggal }\end{array}$ & $\begin{array}{l}\text { Tanda Terima } \\
\text { Untuk }\end{array}$ & No.Kwitansi & $\begin{array}{l}\text { No. Faktur/ } \\
\text { surat Jalan }\end{array}$ & $\begin{array}{l}\text { Jenis barang } \\
\text { /jumlah uang }\end{array}$ \\
\hline & & & & \\
& & & & \\
\hline
\end{tabular}

\section{DAFTAR PUSTAKA}

Agusnawar, Receptionist Hotel, PT. Gramedia Pustaka Utama, Jakarta, 2004

J. Martin, Human Relation for the Hospitality Industry, Van Noostrand Reinhold, English,1991

Rosmawaty, Hambatan - Hambatan Dalam Berkomunikasi, PT. Widya Pajajaran, Bandung, 2010

Soleh Soemirat dan Elvinaro Ardianto, Dasar-Dasar Public Relation, PT. Remaja Rosdakarya, Bandung, 2002

Widjaja, HAW, Pengantar Studi Ilmu Komunikasi, PT. Rineka Cipta, Jakarta, 2000

http://atiahandayani.blogspot.co.id/2012/04/resepsionis.html

http://fitrianirizkiasri.blogspot.co.id/2014/05/syarat-menjadi-resepsionis-yang-baik.html

http://gofaztrack.com/service-excellence/definisi-pelayanan-prima-atau-serviceexcellencel 